\title{
SOCIAL ASPECTS OF VENEREAL DISEASES IN YOUNG PEOPLE IN LEEDS AND LONDON*
}

\author{
BY \\ L. I. PONTING \\ Social Worker, attached to the Lydia Clinic, St. Thomas' Hospital, and the Whitechapel Clinic, The London Hospital
}

This paper is the result of a study carried out under the auspices of the British Federation against the Venereal Diseases in the V.D. clinics of a large hospital in Leeds by Miss J. M. Brignall and of two busy London hospitals by the author. The patients interviewed were all over 13 and under 20 years old, there was no selection, the reason for the survey was explained carefully to each one, and no pressure of any kind was put upon any of them to take part. It was interesting to find that some of them were quite prepared to come back by special appointment and very few refused to take part. In all, forty ( 22 girls and 18 boys) were interviewed in Leeds and 160 ( 97 girls and 63 boys) in London. The age distribution is given in Table $\mathbf{I}$.

TABLE I

AGE OF PATIENTS

\begin{tabular}{c|c|c}
\hline Age (yrs) & Leeds & London \\
\hline 14 & - & 4 \\
15 & 1 & 1 \\
16 & 8 & 24 \\
17 & 13 & 45 \\
18 & 11 & 45 \\
19 & 7 & 41 \\
\hline Total Patients & 40 & 160 \\
\hline
\end{tabular}

The interviews took place in a private room with no third party present. The questions asked aimed at bringing out the home background, religious beliefs, education, and personal relationships. In the preparation of this questionnaire I found that used by Celia Deschin of New York a great help. The young people were very willing to talk about themselves and their problems. Each interview lasted as a rule from $\mathbf{4 0}$ minutes to 2 hours; many thanked me at the end, saying that it was the first time they had

* Paper read at the M.S.S.V.D. meeting in Copenhagen on June 6, 1963. talked to somebody like myself and that the interview had made them think.

At Leeds, Miss Brignall found that in every case the patients came from broken homes, homes where discipline was little known and standards almost non-existent, and where almost certainly very few of the parents knew what their children were doing in their free time, or the kind of company they were keeping. My own conclusions were based not only on the interviews carried out in the clinics but also on my visits to homes and talks with some other patients.

The high incidence of venereal disease in young people cannot be considered by itself; it must be regarded as but one symptom of a general alteration in the manners and customs of young people. This change is due to several factors; since the beginning of the century there has been an obvious decline in the impact of organized religion upon the lives of our people. Parents have tended to send their children to church, but not to attend themselves. There has been a decline in parental authority and many parents do not seem to accept the moral responsibility of bringing up their children to become decent citizens. Mainly because of the two world wars there have been vast social and economic changes, with pressure on all sides to raise the standards of living rather than the worth of living. Young people have been earning more and advertising has been creating the image of a world where, through material consumption, everybody is happy, wealthy, and successful. Not all young people are suited to this life of precocious independence. The majority have been taught the mechanics of sex, but not its emotional aspects. Girls mature earlier, but only physically. Young people receive so little guidance in their most formative years, that it is not very surprising that venereal disease and juvenile delinquency have increased.

Education can give rise to problems and too many young people are only anxious to leave school and 
find a job. The type of schooling received by the young people interviewed is shown in Table II.

TABLE II

TYPE OF SCHOOL ATTENDED BY PATIENTS

\begin{tabular}{l|c|c}
\hline \multicolumn{1}{c|}{ School } & Leeds & London \\
\hline Public & 1 & 4 \\
Convent & 10 & 7 \\
Grammar & 22 & 105 \\
Secondary & 2 & 1 \\
Church & 2 & -6 \\
$\begin{array}{l}\text { Private } \\
\text { British Weal } \\
\text { Educationally Sub-normal }\end{array}$ & - & 5 \\
Total Patients & - & 1 \\
\hline
\end{tabular}

It is only after they have left that these youngsters realize the value of education and regret not having obtained their General Certificate of Education. A fair number, mostly boys, do continue their studies, but there are others. One 17-year-old boy whom I interviewed left school at 15 , works in a stockbroker's office, and now realizes that he cannot get any further without his General Certificate of Education, but said that he would find it hard to give up his evening pleasures to study as he would be constantly thinking of his friends enjoying themselves. Another boy stated, "I am earning $£ 18$ a week and have no prospects, but I could not earn much more, even if I did give my evenings to study, so why should I bother?"

In the old days if anyone did not receive a higher education he could always blame the State or the financial situation of his parents. To-day he knows that he himself has not measured up to the standard required. If only we could make young people see that the level of a man's job and its pay are no guide to the respect we should have for him as a person. I have found a good deal of evidence of social mobility, but only one boy stated that he did not think he would continue his studies because he feared it would take him out of his social class.

Unfortunately, many of the jobs to which these young people are drawn are boring, mechanical, and monotonous, offering very little outlet for natural adolescent emotions and tending to create a sense of frustration. For this reason they take one job after another but find them all equally dull (Table III). I was interested in one boy who stated that, after many changes due to boring work and the fact that he did not like being told what to do, he had joined the Fire Service and intended to make it his career. I said: "Surely in the Fire Service you have to be told what to do". He replied: "Oh yes, but that's different, the work is interesting, you are giving a service and people look up to you".
TABLE III

NUMBER OF JOBS HELD BY THOSE WHO HAD LEFT SCHOOL

\begin{tabular}{c|c|c}
\hline No. of Jobs & Leeds & London \\
\hline 1 & 14 & 25 \\
2 & 8 & 29 \\
3 or More & 11 & 81 \\
\hline Total Patients & 33 & 135 \\
\hline
\end{tabular}

TABLE IV

LIVING ARRANGEMENTS

\begin{tabular}{l|c|c}
\hline Type of Household & Leeds & London \\
\hline Both parents & 19 & 94 \\
Father Only & 3 & 3 \\
Mother Only & - & 15 \\
Mother and Stepfather & - & 9 \\
Husband & 3 & 10 \\
Member of Family & 7 \\
Girl with Girl Friend & - & 6 \\
Girl with Boy Friend & - & 5 \\
Hostel & 3 & 4 \\
Dr. Barnardo's & 40 & 160 \\
Alone & & \\
\hline Total Patients & & \\
\hline
\end{tabular}

The type of home or family is shown in Table IV. Many of the young people that I interviewed come from homes that to all intents and purposes are good homes, but to-day the "family" may give its young people no feeling of security; often each member tends to live as a separate unit and many have never done things as a family, or have ceased to do so at a very early age (Tables $\mathrm{V}$ and VI).

TABLE V

FAMILY ACTIVITIES SHARED BY PATIENTS WITH

\begin{tabular}{l|c|c}
\hline Activity & Leeds & London \\
\hline Entertaining & 12 & 15 \\
Visiting & 10 & 19 \\
Theatre & - & 4 \\
Cinema & 2 & 1 \\
Sport & 9 & 49 \\
Holidays & 13 & 89 \\
\hline Total Patients & & \\
\hline
\end{tabular}

TABLE VI

AGE AT WHICH PATIENTS CEASED TO SHARE FAMILY ACTIVITIES

\begin{tabular}{c|c|c}
\hline Age (yrs) & Leeds & London \\
\hline 9 & 2 & 2 \\
12 & 3 & 5 \\
13 & 4 & 3 \\
14 & 3 & 9 \\
15 & 4 & 19 \\
16 & 2 & 17 \\
17 & 2 & 2 \\
18 & 0 & 9 \\
\hline Not ceased & 22 & 71 \\
\hline Total Patients & 2 & \\
\hline
\end{tabular}


There is often a lack of communication between members of a family. There always has been a natural gap between youth and age, but the gap to-day appears to be far wider.

I feel that many, especially the girls, would prefer to have less freedom, provided they felt that they were not being subjected to restrictions which were needless but were imposed out of a real regard for their well-being.

Of the 160 patients I interviewed in London only nine mentioned the part played by their father in their upbringing. Those that did mention their father said that they had not always understood but were now grateful to him. Unfortunately, the father is often interested and helpful with the children whilst they are small, but later when the financial demands of the family increase and his work becomes more demanding, he may tend to grow away from his family just at the same time when they need him most. The role of the father has become less clearly defined, and I should like to see young fathers taught the important part they can play in the family. Children need a real father, and boys especially need to be able to model themselves on a father figure.

There is no doubt that the early years of a child's life set the pattern for the future. An 18-year-old girl stated that through being spoilt she developed a vile temper and her parents gave in to her for the sake of peace. When she was 16 years old she told her parents that she was pregnant so that she could get married and leave home. The parents finally gave in against their better judgement. The husband is now in prison, his mother is bringing up the child, and the girl is living with another man in one rather squalid room and states that she dare not think of the future.

It is also easy for the over-protected girl to run into trouble. One 19-year-old girl I interviewed had been over-protected by her parents. When for domestic reasons a friend's son came to stay with the family, she deliberately allowed herself to become pregnant because she knew that her parents would insist on marriage. She was married at 16 , and had a very difficult time during the pregnancy. The husband, who was too immature and unsettled, started going out with other girls, so that the young wife is now separated and her parents are helping to bring up the child.

Too strict an upbringing can also give rise to problems. A 17-year-old girl from a Catholic family, who was educated at a convent school, stated that her parents had recently separated; she had received no pocket money, had not been allowed to smoke or drink, and had been very strictly brought up. She had had her first sexual experience 6 months ago (with a man 6 years older than herself) because she "thought it was time she gained experience". They met in a coffee bar and the love-making took place in his car. She said that she felt at a disadvantage, because the girls at work talked about things she knew nothing about, and she did not want to go on being "odd man out".

Of the families of the 160 young people I interviewed, 32 mothers worked full-time and 45 parttime. An 18-year-old boy stated that his mother had always worked full-time, leaving home at 6 every morning. He had always had to see himself off to school and if he was late he just did not go. He has had both homosexual and heterosexual experiences, but has not yet had a real girl friend-he had only been with a paid girl. His elder brother got a girl into trouble and married her, but the marriage does not appear to be a success. He thought that girls were only interested in marriage. He had paid 9 guineas for his shoes, had been to Spain for his holiday, and owns an Austin 7 car, but if he was in trouble there was nobody that he could go to.

Table VII suggests that our present methods of sex instruction are inadequate. The majority of those interviewed first learned about sex from other children, which means that they have had wrong ideas about sex from the start. They do not learn the part that marriage should play in the community, or that marriage should be built on a more permanent foundation than sex alone.

TABLE VII

HOW PATIENTS FIRST LEARNED ABOUT SEX

\begin{tabular}{l|c|c}
\hline \multicolumn{1}{c|}{ Source } & Leeds & London \\
\hline Mother & 7 & 7 \\
Father & $\frac{7}{3}$ & 30 \\
School & 12 & 116 \\
Other Children & 3 & 4 \\
\hline Other Sources & 40 & 160 \\
\hline Total Patients & & \\
\hline
\end{tabular}

It has been said that the ease with which it is possible to buy contraceptives makes it easier for people to have sex relations. Of the $160 \mathrm{I}$ interviewed, only four girls and 23 boys took "precautions", and ten of the boys who had sex relations with too many girls to count used none!

More needs to be done to make the fact of venereal disease known to the general public, since many young people still think that only one type of person is likely to pick it up. Some parents still do not seem to realize what their children are doing or the hazards facing them. For example, one boy told me that his father was reading a newspaper when the 
boy caught sight of an article on V.D. and asked, "What's that, Dad?". The father hastily folded up the paper and said "Nothing, son". The son now attends a V.D. clinic. Only 51 of the $160 \mathrm{I}$ interviewed admitted to being afraid of V.D.

What makes young people indulge in sex at a very early age? In some cases, loneliness and lack of security. Of the forty young people interviewed by Miss Brignall in Leeds, nineteen admitted to being lonely. Young people often indulge in heavy petting -one 17-year-old grammar school boy, friendly with an 18-year-old grammar school girl, stated that they had started by heavy petting and just went too far. He has no intentions of marrying the girl although he does feel a certain amount of responsibility for her as she was a virgin. His ambition is to go to the University and he hopes this will end the friendship without hard feelings; at present he has just enough money, sex, drink, education, and opportunity for further education to keep him contented.

Some engaged couples think there is nothing wrong in pre-marital sex relations, but engagements especially between very young people, are not always permanent. One 18-year-old girl, who lives in a small town with her parents, has been engaged twice and has had sex relations with both fiancés. Unfortunately, somebody made anonymous telephone calls to the parents of girls in the area, informing them that their daughters had been having sexual intercourse. The mother was understanding, but the father was upset and so far has been unable to forgive his daughter.

For many sex is a mere physical exercise, involving no deep emotional feelings (Table VIII). Some of the young people I have seen came to the clinic as the result of an office party. Quite often they have not been used to alcohol, but have not liked to refuse as to do so would make them lose face. After the party they tended to pair off. Some days later another girl remarks: "You know that young man you went with, I've heard he has got something wrong with him, he's attending a clinic". The whole thing comes as

TABLE VIII

NUMBER OF PERSONS WITH WHOM PATIENTS HAD HAD SEXUAL RELATIONS

\begin{tabular}{c|c|c}
\hline No. of Contacts & Leeds & London \\
\cline { 2 - 3 } & 12 & 47 \\
2 & 12 & 29 \\
3 & 6 & 19 \\
4 & 9 & 11 \\
5 & - & 52 \\
Petting only & 39 & 160 \\
\hline Total Patients & - & \\
\hline
\end{tabular}

a great shock and there are many tears. The same sort of thing may happen at an all-night party, only in this case the girl has sex relations not because of drink but because her resistance is lowered in the early hours of the morning. Some belong to a gang and are called chicken by the others if they do not have sexual intercourse. Others have intercourse because it is the done thing or because they are afraid of losing their boy friend-I have also interviewed a few 14-year-olds who attended the clinic as the result of a game they had been playing, called "King's Command"; one of the things they had been ordered to do was to have intercourse. Some do it for "kicks". One boy told me that at parties he used deliberately to ply a girl with drinks, and try to persuade her to have intercourse with him, when he thought she had drunk just the right amount. To him this was a fascinating game.

There is no doubt that the commercialization of sex makes a strong impact on many young people. One girl said: "Your parents tell you not to, but the films, magazines, advertising posters, and records all present such a glamorous and attractive picture of sex, that you want to know what it is all about, and of course it is the first step that counts".

Sex was never meant to be just for "kicks", a game, a status symbol, the latest fashion, or sold like a commercial article. We should try and show young people the true meaning of sex, and teach them to respect each other's bodies. We must also show them the other side of the picture: the shock of attending a V.D. clinic, of becoming an unmarried mother, or of trying to procure an abortion. And what of the illegitimate children, what will the future hold for them, especially the half-caste children ? Seven of the girls I interviewed had coloured boy-friends.

How can we help young people? Is religion the answer? I often ponder on the fact that, though many people decry religion, nobody has yet found anything to take its place. Is it the family? If only we could show young people that there is nothing more rewarding than a secure and happy family life. Is it education? We are living in an era of social change. It is possible that young people will tend to have weaker family ties, that increasing automation will make life even more boring, and it is therefore important that this should be compensated for by a school life which gives a strong sense of guidance in which young people can feel that they belong to a purposeful group of their own age. This will be easier to achieve when the school-leaving age is raised to 16 years, though I feel that for many the answer lies rather in part-time further education. If the family cannot do so the school must prepare young people for their working and social life and 
teach them to give to the community as well to accept its benefits.

The final solution however rests with the young people themselves. No generation has had a perfect upbringing, and those of our century must learn to accept the challenge of their age. I was very pleased to hear that a group of sixth-formers and students were launching a nation-wide campaign against the commercial exploitation of sex and "snogging" parties.

I should like to thank Miss J. M. Brignall, Head Almoner, The General Infirmary, Leeds, for allowing me to use her material, and Mr. Ambrose King, Dr. C. S. Nicol, Dr. R. D. Catterall, and the staffs of the V.D. clinics concerned for their valuable help and co-operation. 